\title{
Vegetative and Reproductive Response of Olive Cultivars to Moderate Saline Water Irrigation
}

\author{
Sebastian Weissbein \\ Phyto-Lipid Biotechnology Laboratory, Department of Biotechnology \\ Engineering, Faculty of Engineering, and Ben-Gurion University of the \\ Negev, Beer-Sheva, 84105, Israel; and The Jacob Blaustein Institutes for \\ Desert Research, Ben-Gurion University of the Negev, Beer-Sheva, 84105, \\ Israel
}

\section{Zeev Wiesman ${ }^{1}$}

Phyto-Lipid Biotechnology Laboratory, Department of Biotechnology Engineering, Faculty of Engineering, Ben-Gurion University of the Negev, Beer-Sheva, 84105, Israel

\section{Yhonathan Ephrath and Moshe Silberbush \\ The Jacob Blaustein Institutes for Desert Research, Ben-Gurion University of the Negev, Beer-Sheva, 84105, Israel}

Additional index words. olive cultivars, salinity, irrigation, semiarid, electrical conductivity

\begin{abstract}
Selected superior olive cultivars cultivated on a large scale in various countries in the Mediterranean region were tested in a special saline irrigation experimental plot established in 1997 in the center of the semiarid Israeli Negev area. The plot comprised two subplots containing the same 12 olive cultivars in a mirror image design. One subplot was drip-irrigated with tap water $\left(1.2 \mathrm{dS} \cdot \mathrm{m}^{-1}\right)$ and the second with moderate saline water $\left(4.2 \mathrm{dS} \cdot \mathrm{m}^{-1}\right)$. All cultivation practices applied to the two subplots were similar in terms of fertilization, irrigation, soil leaching, and so on. The present study summarizes the vegetative and reproductive response of the tested olive cultivar trees during the 5 years after they reached maturation and full yield. Evaluation of trunk growth, olive yield, oil percentage, olive oil yield, and fatty acid composition of the oil, sodium and chloride leaf levels, and soil fractions up to $90 \mathrm{~cm}$ enabled characterization and comparison of the horticultural performance of the various olive cultivars intensively cultivated with the two tested irrigation treatments. The data clearly showed a significant difference between the tested cultivars in terms of growth, yield, and oil parameters. Grouping the tested cultivars in terms of olive oil production yielded the following three groups: Group A-'Barnea', 'Maalot', and 'Picholin'-their average oil yield ranged from 8 to $10 \mathrm{~kg} /$ tree; Group B-'Souri', 'Frantoio', 'Leccino', 'Arbequina', 'Picual', 'Kalamata', 'Koroneiki', and 'Picholin di Morroco'-their average oil yield ranged from 5 to $8 \mathrm{~kg} /$ tree; and Group C-'Picudo'—ranged from 3 to $4 \mathrm{~kg} /$ tree. Saline irrigation treatment at $4.2 \mathrm{dS} \cdot \mathrm{m}^{-1}$ demonstrated only a low rate of retardation effect on growth or yield of olive trees compared with water at $1.2 \mathrm{dS} \cdot \mathrm{m}^{-1}$ of the same cultivar in each subplot. The data obtained from the present study suggest that efficient productive cultivation of mature olive cultivars in Israeli Negev semiarid conditions, irrigated with moderate saline water, is closely related to proper soil leaching methodology and maintaining the soil electrical conductivity level in the root zone in a range lower than $6 \mathrm{dS} \cdot \mathrm{m}^{-1}$.
\end{abstract}

As a result of increased demand for healthy sources of fat for human consumption and the fact that olives are considered to be well-adapted to semiarid conditions, an intensive wave of olive planting has taken place in the last decade in many places worldwide [Food and Agriculture Organization (FAO), 1989]. Traditionally, olives have been cultivated in the Mediterranean region and many superior cultivars have been

Received for publication 9 June 2007. Accepted for publication 24 Oct. 2007.

${ }^{1}$ To whom reprint requests should be addressed; e-mailwiesman@bgu.ac.il the vegetative and reproductive development of olives mainly as a result of interference with the osmotic balance in the root system zone and detrimental effects caused by specific toxic accumulation of chloride and sodium ions in the leaves (Benlloch et al., 1991; Bongi and Loreto, 1989; Hassan et al., 2000; Maas and Grattan, 1999; Tattini, 1994). Salinity is known to be a common limiting factor in semiarid areas, even when tap water is used, as a result of the high rate of water evaporation (Shalhevet, 1994).

The FAO (1985) classifies olive trees as "moderately tolerant" to salinity, suggesting a threshold electrical conductivity (EC) of the soil saturation extract between 3 and 6 $\mathrm{dS} \cdot \mathrm{m}^{-1}$. Although the threshold chloride and sodium ions toxic concentrations varied, as a result of different experimental conditions and tested genotypes, most studies concluded that they are $\approx 2 \mathrm{mg} \cdot \mathrm{g}^{-1}$ of $\mathrm{Cl}^{-}$and 4 to 5 $\mathrm{mg} \cdot \mathrm{g}^{-1}$ sodium on a leaf dry weight basis, and it was suggested that injury is better correlated with sodium than with chloride (AlSaket and Aesheh, 1987; Bernstein, 1975; Gucci and Tattini 1997; Klein et al., 1994). Recently, Aragues et al. (2005) reported on 'Arbequina' olive tree trunk growth reduction with chloride levels higher than 2.3 $\mathrm{mg} \cdot \mathrm{g}^{-1}$ and sodium levels higher than 1.5 $\mathrm{mg} \cdot \mathrm{g}^{-1}$.

Most reports have focused on the physiological mechanisms involved in olive tree response to saline soil and water conditions. As a result of the long time until olive trees reach maturity and their yielding phase, the majority of these studies has been carried out with solution cultures or greenhouse pot trials using young olive seedlings or plants and has focused on specific cultivars tested in various environmental conditions and cultivation practices. As a result of these experimental limitations, the results cannot be easily extrapolated to field conditions. A limited number of field trials analyzing the response of some specific olive cultivars using various cultivation practices and at different maturation stages have been reported in recent years (Aragues et al., 2005; Klein et al., 1994; Murillo et al., 2000; Wiesman et al., 2004). Even in these studies, relatively young trees were used and the sustainable effect of salinity on the olive trees was not studied for a significant period of time. In addition, salinity tolerance parameters are not well established, especially in mature trees, and were not well enough analyzed in field conditions. Thus, the actual impact of salinity on the yield of olives is uncertain. It is difficult to reach general conclusions and to predict the response of most olive cultivars to intensive cultivation under saline-irrigated semiarid conditions.

To support the rapidly growing olive industry in the semiarid south part of Israel and similar areas in the world, in 1997, we established a new special saline irrigation controlled experimental plot. Twelve selected superior local olive cultivars and cultivars from various Mediterranean countries were planted in this plot that was divided 
into two identical subplots: one was irrigated with tap water $\left(1.2 \mathrm{dS} \cdot \mathrm{m}^{-1}\right)$ and the second was irrigated with moderate saline water $\left(4.2 \mathrm{dS} \cdot \mathrm{m}^{-1}\right)$. In the present study, we aimed to evaluate and compare the vegetative and reproductive multiannual response of mature yielding trees of the 12 tested olive cultivars drip-irrigated with tap water and moderate saline water in a commercial orchard simulation study in a semiarid area.

\section{Materials and Methods}

Experimental. The experiment was conducted in the Ramat Negev Experimental Station situated in the center of the south part of the Israeli semiarid Negev area, near Wadi Ha Besor, $30 \mathrm{~km}$ south of Beer-Sheva (lat. $31^{\circ} 05^{\prime} 00^{\prime \prime}$, long. $34^{\circ} 41^{\prime} 03^{\prime \prime}, 305 \mathrm{~m}$ above sea level). The soil verge common in the Experimental Station is light loess, $6 \%$ to $8 \%$ clay, $\mathrm{pH} 7.2$ to 7.4 to 8.0 . The average annual rainfall in this area is $\approx 50 \mathrm{~mm}$.

Twelve olive cultivars from various olivegrowing countries in the Mediterranean basin were planted in 1997 in a special saline water irrigation testing plot. Olive cultivars selected in Israel, Italy, Spain, Greece, France, and Morocco of 10 or six plants each (Table 1) were planted in mirror-like image blocks of two identical subplots. The planting distance between plants and rows were $4 \mathrm{~m} \times$ $6 \mathrm{~m}$, respectively, representing a density of 240 plants/ha. One subplot was irrigated with tap water $\left(1.2 \mathrm{dS} \cdot \mathrm{m}^{-1} \mathrm{EC}\right)$ as a control and the second with moderate saline water $\left(4.2 \mathrm{dS} \cdot \mathrm{m}^{-1} \mathrm{EC}\right)$. The olive trees were dripirrigated using a basic monthly irrigation formula that was developed based on multiyear local pan evaporation data (Table 2). This formula was continuously rechecked on a daily basis and corrected accordingly. The average quantity of water applied annually was $6560 \mathrm{~m}^{3} \cdot \mathrm{ha}^{-1}$. During the first 4 years after planting, the practice was immediate irrigation after any rainfall to prevent salinization of the root zone area. Usually twice a year, in March and November, a supplement of $1000 \mathrm{~m}^{-3}$ was added to the monthly water to leach the soil and remove the salt excess from the root system zone (Wiesman et al., 2004). The tap water used was supplied by the Israeli National Water Carrier and the saline water was drawn from local wells, where the water level was $\approx 300 \mathrm{~m}$ below the surface. The EC of the water for the saline treatment was adjusted by mixing the two types of water or adding $\mathrm{NaCl}$. The rate of $\mathrm{N}-\mathrm{P}-\mathrm{K}$ fertilization was determined based on the results of annual nutrient leaf analysis. All the olive trees in the experimental plot developed well for the first 2 years and gradually started to be productive from the third year according to the cultivar. Thus, the study was initiated from the fourth year (2001).

Field measurements. Every year during the study, the trunk circumference of each tree was measured twice at the same marked location (30 $\mathrm{cm}$ aboveground). Based on the olive maturity index (Barranco et al., 1998),

Table 1. Mediterranean olive cultivars planted in 1997 in the plot used for the study.

\begin{tabular}{lcl}
\hline Cultivar & Number of trees & Origin \\
\hline Barnea & 10 & Israel \\
Souri & 10 & Israel \\
Maalot & 6 & Israel \\
Frantoio & 10 & Italy \\
Leccino & 10 & Italy \\
Arbequina & 10 & Spain \\
Picual & 10 & Spain \\
Picudo & 10 & Spain \\
Kalamata & 6 & Greece \\
Koroneiki & 10 & Greece \\
Picholin & 10 & France \\
Picholin di Morocco & 6 & Morocco \\
Total & 108 & \\
\hline
\end{tabular}

Table 2. Annual distribution of water supplied by irrigation to the tested olive plots.

\begin{tabular}{lr}
\hline Month & $\mathrm{m}^{3} \cdot \mathrm{ha}^{-1} / \mathrm{mo}^{-1}$ \\
\hline January & 230 \\
February & 270 \\
March & $450+1000^{\mathrm{z}}$ \\
April & 700 \\
May & 780 \\
June & 810 \\
July & 900 \\
August & 1000 \\
September & 760 \\
October & 460 \\
November & $1000^{\mathrm{z}}$ \\
December & 200 \\
Total & 8560 \\
\hline${ }^{ }$Water was added to the monthly quantity to leach
\end{tabular}

the soil and remove excess salt.

Table 3. Comparison of annual trunk circumference increase in trees of all tested olive cultivars irrigated with saline water versus irrigation with tap water.

A. Trunk circumference analysis in the time period 2001 to 2005 .

\begin{tabular}{|c|c|c|c|c|c|c|c|c|}
\hline \multirow[b]{2}{*}{ Cultivar } & \multirow[b]{2}{*}{$\begin{array}{l}\text { Salinity } \\
\left(\mathrm{dS} \cdot \mathrm{m}^{-1}\right)\end{array}$} & \multicolumn{6}{|c|}{ Trunk circumference $(\mathrm{cm})$} & \multirow{2}{*}{$\begin{array}{l}\text { Avg trunk } \\
\text { growth } \\
\text { (cm/yr) }\end{array}$} \\
\hline & & $\begin{array}{l}\text { Nov. } \\
2001\end{array}$ & $\begin{array}{l}\text { Oct. } \\
2002\end{array}$ & $\begin{array}{l}\text { Sept. } \\
2003\end{array}$ & $\begin{array}{l}\text { Dec. } \\
2004\end{array}$ & $\begin{array}{l}\text { May } \\
2005\end{array}$ & $\begin{array}{l}\text { Oct. } \\
2005\end{array}$ & \\
\hline \multicolumn{9}{|l|}{ Israeli origin } \\
\hline Barnea & 1.2 & 37.0 a x y & $42.4 \mathrm{a}$ & 48.5 a x y & $50.8 \mathrm{a}$ & $52.8 \mathrm{a}$ & 57.4 a x y & 5.1 \\
\hline Barnea & 4.2 & 34.5 a x y & $38.2 \mathrm{a}$ & 45.9 a x y & $51.2 \mathrm{a}$ & $54.1 \mathrm{a}$ & 57.6 a x y & 5.8 \\
\hline Souri & 1.2 & 33.4 a x y & $42.8 \mathrm{a}$ & 50.5 a x y & $55.3 \mathrm{a}$ & $59.6 \mathrm{a}$ & 60.9 a x y & 6.9 \\
\hline Souri & 4.2 & 32.6 a x y & $38.8 \mathrm{a}$ & 46.5 a x y & $51.5 \mathrm{a}$ & $53.7 \mathrm{a}$ & 55.6 a x y & 5.7 \\
\hline Maalot & 1.2 & 37.8 a x & $47.3 \mathrm{a}$ & $54.7 \mathrm{ax}$ & $59.7 \mathrm{a}$ & $62.3 \mathrm{a}$ & 65.0 a x & 6.8 \\
\hline Maalot & 4.2 & 34.2 a x y & $43.6 \mathrm{a}$ & $53.0 \mathrm{a} \mathrm{x}$ & $60.7 \mathrm{a}$ & $63.5 \mathrm{a}$ & $69.2 \mathrm{ax}$ & 8.7 \\
\hline \multicolumn{9}{|l|}{ Italian origin } \\
\hline Frantoio & 1.2 & 37.2 a x y & $41.8 \mathrm{a}$ & 47.7 a x y & $51.4 \mathrm{a}$ & $52.7 \mathrm{a}$ & 56.3 a x y & 4.8 \\
\hline Frantoio & 4.2 & $31.1 \mathrm{bxy}$ & $37.0 \mathrm{a}$ & 44.8 a x y & $48.7 \mathrm{a}$ & $55.0 \mathrm{a}$ & 55.9 a x y & 6.2 \\
\hline Leccino & 1.2 & 38.7 a x & $46.2 \mathrm{a}$ & $53.2 \mathrm{ax}$ & $56.6 \mathrm{a}$ & $58.5 \mathrm{a}$ & $63.0 \mathrm{ax}$ & 6.1 \\
\hline Leccino & 4.2 & $37.7 \mathrm{a} x$ & $44.4 \mathrm{a}$ & $52.5 \mathrm{ax}$ & $57.5 \mathrm{a}$ & $59.5 \mathrm{a}$ & $63.7 \mathrm{ax}$ & 6.5 \\
\hline \multicolumn{9}{|l|}{ Spanish origin } \\
\hline Arbequina & 1.2 & $27.1 \mathrm{a} \mathrm{y}$ & $35.2 \mathrm{a}$ & 41.0 a x y & $44.1 \mathrm{a}$ & $45.9 \mathrm{a}$ & 50.8 a y & 5.9 \\
\hline Arbequina & 4.2 & $27.0 \mathrm{a} y$ & $33.2 \mathrm{a}$ & 40.3 a y & $43.2 \mathrm{a}$ & $45.8 \mathrm{a}$ & $48.1 \mathrm{a} y$ & 5.3 \\
\hline Picual & 1.2 & $37.8 \mathrm{ax}$ & $43.2 \mathrm{a}$ & 50.0 a x y & $54.1 \mathrm{a}$ & $56.7 \mathrm{a}$ & 62.9 a x y & 6.3 \\
\hline Picual & 4.2 & 34.0 a x y & $38.2 \mathrm{a}$ & 46.0 a x y & $51.0 \mathrm{a}$ & $53.0 \mathrm{a}$ & 59.7 a x y & 6.4 \\
\hline Picudo & 1.2 & 31.5 a x y & $35.1 \mathrm{a}$ & 43.8 a x y & $46.3 \mathrm{a}$ & $47.6 \mathrm{a}$ & 50.2 a y & 4.7 \\
\hline Picudo & 4.2 & 26.4 a y & $32.6 \mathrm{a}$ & 40.3 a y & $46.9 \mathrm{a}$ & $49.5 \mathrm{a}$ & 53.3 a y & 6.7 \\
\hline \multicolumn{9}{|l|}{ Greek Origin } \\
\hline Kalamata & 1.2 & 25.9 a y & $33.5 \mathrm{a}$ & 41.7 a x y & $46.5 \mathrm{a}$ & $49.0 \mathrm{a}$ & $51.2 \mathrm{a} y$ & 6.3 \\
\hline Kalamata & 4.2 & 22.2 a x y & $30.7 \mathrm{a}$ & 39.7 а y & $45.0 \mathrm{a}$ & $48.2 \mathrm{a}$ & 50.5 a y & 7.0 \\
\hline Koroneiki & 1.2 & 29.9 a x y & $35.6 \mathrm{a}$ & 43.5 a x y & $47.9 \mathrm{a}$ & $49.4 \mathrm{a}$ & 50.6 a x y & 5.2 \\
\hline Koroneiki & 4.2 & 26.4 a y & $30.4 \mathrm{a}$ & 42.2 a y & $43.8 \mathrm{a}$ & $44.1 \mathrm{a}$ & 48.1 a y & 5.4 \\
\hline \multicolumn{9}{|l|}{ French Origin } \\
\hline Picholin & 1.2 & 33.8 a x y & $39.4 \mathrm{a}$ & 48.5 a x y & $53.6 \mathrm{a}$ & $55.2 \mathrm{a}$ & 59.2 a x y & 6.3 \\
\hline Picholin & 4.2 & 35.3 a x y & $37.8 \mathrm{~b}$ & 48.1 a x y & $52.5 \mathrm{a}$ & $54.4 \mathrm{a}$ & 60.0 a $x y$ & 6.2 \\
\hline \multicolumn{9}{|l|}{ Morocco Origin } \\
\hline P. Morocco & 1.2 & 28.9 a x y & $38.0 \mathrm{a}$ & 46.8 a x y & $52.0 \mathrm{a}$ & $54.0 \mathrm{a}$ & 57.0 a $x y$ & 7.0 \\
\hline P. Morocco & 4.2 & $23.5 \mathrm{a} \mathrm{y}$ & $38.7 \mathrm{a}$ & $45.3 \mathrm{a} \times \mathrm{y}$ & $52.3 \mathrm{a}$ & $58.5 \mathrm{a}$ & 60.7 a x y & 9.3 \\
\hline
\end{tabular}

Tukey-Kramer test $(P \leq 0.01)$ was carried out between two saline level treatments $\left(1.2 \mathrm{dS} \cdot \mathrm{m}^{-1}\right.$ and $4.2 \mathrm{dS} \cdot \mathrm{m}^{-1}$ ) (letters a and $\mathrm{b}$ ) and between all the tested cultivars in both treatments (letters $\mathrm{x}$ and $\mathrm{y}$ ). Levels not connected by same letter are significantly different.

Table 3B. Tukey-Kramer analysis of variance of the effect of cultivars and treatments on trunk circumference.

\begin{tabular}{lccccccc}
\hline Source & $\begin{array}{c}\text { Degrees of } \\
\text { freedom }\end{array}$ & $\begin{array}{c}\text { F } \\
\text { value }\end{array}$ & $\begin{array}{c}\text { Nov. } \\
2001\end{array}$ & $\begin{array}{c}\text { F } \\
\text { value }\end{array}$ & $\begin{array}{c}\text { Sept. } \\
2003\end{array}$ & $\begin{array}{c}\text { F } \\
\text { value }\end{array}$ & $\begin{array}{c}\text { Oct. } \\
2005\end{array}$ \\
\hline Cultivar & 11 & 10.55 & $* *$ & 7.32 & $* *$ & 9.23 & $* *$ \\
Treatment & 1 & 13.59 & $*$ & 7.59 & NS & 0.08 & NS \\
Cultivar*treatment & 11 & 0.84 & NS & 0.39 & NS & 0.63 & NS \\
\hline
\end{tabular}

**High significance effect $P<0.001$; *low significance effect $P<0.05$; NS $=$ nonsignificant.

fully ripened olives from individual trees were harvested separately and the olive yield of each cultivar was assessed for every tree in each subplot. Olive samples of each cultivar were collected at different develop- mental stages beginning with olive stone hardening, until harvesting. Five replicates of batches of 10 olives were randomly chosen and used for average weight and diameter determination. 
Table 4. Comparison of olive yield per tree in all tested olive cultivars irrigated with saline water versus irrigation with tap water.

A. Olive yield analysis in the time period 2001 to 2004 .

\begin{tabular}{|c|c|c|c|c|c|c|}
\hline \multirow[b]{2}{*}{ Cultivar } & \multirow{2}{*}{$\begin{array}{l}\text { Salinity } \\
\left(\mathrm{dS} \cdot \mathrm{m}^{-1}\right)\end{array}$} & \multicolumn{4}{|c|}{ Olive yield $(\mathrm{kg} /$ tree $)$} & \multirow[b]{2}{*}{ Avg } \\
\hline & & 2001 & 2002 & 2003 & 2004 & \\
\hline \multicolumn{7}{|l|}{ Israeli origin } \\
\hline Barnea & 1.2 & $38.3 \mathrm{a}$ & $55.1 \mathrm{a}$ & $41.3 \mathrm{a}$ & $76.6 \mathrm{a}$ & 54.8 a x \\
\hline Barnea & 4.2 & $33.7 \mathrm{a}$ & $52.8 \mathrm{a}$ & $23.0 \mathrm{~b}$ & $84.5 \mathrm{a}$ & $52.2 \mathrm{ax}$ \\
\hline Souri & 1.2 & $5.0 \mathrm{a}$ & $20.3 \mathrm{a}$ & $33.1 \mathrm{a}$ & $51.1 \mathrm{a}$ & 31.8 a y \\
\hline Souri & 4.2 & $4.2 \mathrm{a}$ & $22.6 \mathrm{a}$ & $36.9 \mathrm{a}$ & $52.8 \mathrm{a}$ & 31.5 a y \\
\hline Maalot & 1.2 & $\mathrm{ND}$ & $32.0 \mathrm{a}$ & $39.6 \mathrm{a}$ & $40.7 \mathrm{a}$ & $37.5 \mathrm{a} y$ \\
\hline Maalot & 4.2 & $\mathrm{ND}$ & $21.0 \mathrm{a}$ & $27.5 \mathrm{a}$ & $52.8 \mathrm{a}$ & 33.8 a y \\
\hline \multicolumn{7}{|l|}{ Italian origin } \\
\hline Frantoio & 1.2 & $10.5 \mathrm{~b}$ & $54.5 \mathrm{a}$ & 0.0 & $66.7 \mathrm{a}$ & 38.6 a y \\
\hline Frantoio & 4.2 & $23.8 \mathrm{a}$ & $36.6 \mathrm{~b}$ & 0.0 & $66.0 \mathrm{a}$ & 31.6 a y \\
\hline Leccino & 1.2 & $9.2 \mathrm{a}$ & $36.0 \mathrm{a}$ & $38.4 \mathrm{a}$ & $71.2 \mathrm{a}$ & 46.1 a x y \\
\hline Leccino & 4.2 & $12.2 \mathrm{a}$ & $37.2 \mathrm{a}$ & $27.7 \mathrm{a}$ & $78.7 \mathrm{a}$ & 45.7 a x y \\
\hline \multicolumn{7}{|l|}{ Spanish origin } \\
\hline Arbequina & 1.2 & $12.3 \mathrm{a}$ & $38.2 \mathrm{a}$ & $43.7 \mathrm{a}$ & $51.6 \mathrm{a}$ & 42.5 a x y \\
\hline Arbequina & 4.2 & $25.5 \mathrm{a}$ & $31.9 \mathrm{a}$ & $50.0 \mathrm{a}$ & $57.9 \mathrm{a}$ & 45.3 a x y \\
\hline Picual & 1.2 & $30.5 \mathrm{a}$ & $41.4 \mathrm{a}$ & $11.0 \mathrm{a}$ & $77.4 \mathrm{a}$ & 42.5 a x y \\
\hline Picual & 4.2 & $16.5 \mathrm{a}$ & $44.3 \mathrm{a}$ & $13.0 \mathrm{a}$ & $77.9 \mathrm{a}$ & 43.3 a x y \\
\hline Picudo & 1.2 & $2.0 \mathrm{~b}$ & $42.6 \mathrm{a}$ & $8.3 \mathrm{a}$ & $50.6 \mathrm{a}$ & 31.9 a y \\
\hline Picudo & 4.2 & $5.5 \mathrm{a}$ & $25.0 \mathrm{~b}$ & $17.0 \mathrm{a}$ & $55.0 \mathrm{a}$ & 30.7 a y \\
\hline \multicolumn{7}{|l|}{ Greek origin } \\
\hline Kalamata & 1.2 & ND & $16.2 \mathrm{a}$ & $37.5 \mathrm{a}$ & $40.4 \mathrm{a}$ & 30.3 a y \\
\hline Kalamata & 4.2 & $\mathrm{ND}$ & $15.1 \mathrm{a}$ & $41.1 \mathrm{a}$ & $51.9 \mathrm{a}$ & 38.5 a y \\
\hline Koroneiki & 1.2 & $11.0 \mathrm{a}$ & $53.5 \mathrm{a}$ & $24.1 \mathrm{a}$ & $58.0 \mathrm{a}$ & 44.4 a x y \\
\hline Koroneiki & 4.2 & $15.8 \mathrm{a}$ & $28.6 \mathrm{~b}$ & $21.7 \mathrm{a}$ & $55.7 \mathrm{a}$ & 33.1 a y \\
\hline \multicolumn{7}{|l|}{ French origin } \\
\hline Picholin & 1.2 & $19.1 \mathrm{a}$ & $67.6 \mathrm{a}$ & $11.5 \mathrm{~b}$ & $88.4 \mathrm{~b}$ & $53.6 \mathrm{a} \mathrm{x}$ \\
\hline Picholin & 4.2 & $26.6 \mathrm{a}$ & $57.0 \mathrm{~b}$ & $23.4 \mathrm{a}$ & $102.9 \mathrm{a}$ & $59.0 \mathrm{ax}$ \\
\hline \multicolumn{7}{|l|}{ Morocco origin } \\
\hline P. Morocco & 1.2 & ND & $34.0 \mathrm{a}$ & $21.7 \mathrm{a}$ & $54.0 \mathrm{a}$ & 36.6 a y \\
\hline P. Morocco & 4.2 & $\mathrm{ND}$ & $7.33 \mathrm{~b}$ & $28.6 \mathrm{a}$ & $69.1 \mathrm{a}$ & $35.0 \mathrm{ay}$ \\
\hline
\end{tabular}

Fisher test $(P \leq 0.05)$ was done between two saline treatment levels $\left(1.2 \mathrm{dS} \cdot \mathrm{m}^{-1}\right.$ and $\left.4.2 \mathrm{dS} \cdot \mathrm{m}^{-1}\right)$ (letters $\mathrm{a}$ and $\mathrm{b}$ ) and between all the tested cultivars in both treatments (letters $\mathrm{x}$ and $\mathrm{y}$ ). Levels not connected by same letter are significantly different.

$\mathrm{ND}=$ not detected.

Table 4B. Fisher analysis of variance of the effect of cultivars and treatments on olive yield.

\begin{tabular}{lccc}
\hline Source & Degrees of freedom & F value & Significance \\
\hline Cultivar & 11 & 3.81 & $*$ \\
Treatment & 1 & 0.11 & NS \\
Cultivar*treatment & 11 & 0.30 & NS \\
\hline
\end{tabular}

*Highly significant effect at $P \leq 0.01$; NS = nonsignificant.

Oil percentage determination. The oil percentage was determined using IR Horiba 350 (Irvine, CA), an infrared system specifically for determination of oil content in olive tissue (Wiesman et al., 2004). Briefly, $1 \mathrm{~g}$ of crushed olives from each cultivar was taken, $10 \mathrm{~mL}$ of tetrachloroethylene was added, and the sample was vortexed and kept overnight. One aliquot of $0.06 \mathrm{~mL}$ from the tetrachloroethylene phase was taken and measured on the Horiba system. The results were expressed as a percentage of the total fresh weight.

Olive oil fatty acid profile analysis. Methyl esters of the oil were prepared according to the procedure of the International Olive Oil Council (IOOC) regulations (IOOC, 1995; IUPAC, 1992). In a 5-mL tube, $0.1 \mathrm{~g}$ oil was weighed and diluted with $2 \mathrm{~mL}$ heptane and $0.2 \mathrm{~mL}$ of $2 \mathrm{~N}$ methanolic potassium hydroxide solution was added. The combined solution was shaken vigorously for $30 \mathrm{~s}$ and left to stratify until the upper solution became clear. This solution was collected and evaporated to dryness under $\mathrm{N}_{2}$ gas flow; the methyl esters were resuspended in $1000 \mu \mathrm{L}$ of heptane and analyzed by gas chromatography: column temperature: 120 to $190{ }^{\circ} \mathrm{C}\left(4^{\circ} \mathrm{C}\right.$ per minute $)$, injector temperature: $250{ }^{\circ} \mathrm{C}$, detector temperature: $300^{\circ} \mathrm{C}$, linear velocity of the carrier gas: nitrogen $30 \mathrm{~cm} \cdot \mathrm{s}^{-1}$, hydrogen 20 to $30 \mathrm{~cm} \cdot \mathrm{s}^{-1}$, and air $300 \mathrm{~cm} \cdot \mathrm{s}^{-1} ; 4 \mu \mathrm{L}$ of the resuspended methyl esters solution was injected. The percentage of each acid was calculated according to the formula: $\% \mathrm{X}=$ $($ area $\mathrm{X} \times 100) /$ total area.

Leaf mineral analyses. The leaf analyses were carried out in three pools of 30 leaves collected from each cultivar. Leaf samples were dried at $70{ }^{\circ} \mathrm{C}$, ground, and digested with sulfuric acid. Chloride was determined by titration with $0.5 \mathrm{~N} \mathrm{AgNO}_{3}$, whereas sodium and other elements were determined using Flame Atomic Absorption Spectrometry (Varian, Australia).

Soil mineral analysis. Samples of soil were taken from 0 to 30,30 to 60 , and 60 to $90-\mathrm{cm}$ soil column fractions. At least four randomized replicates of each subplot irrigated with $1.2 \mathrm{dS} \cdot \mathrm{m}^{-1}$ and $4.2 \mathrm{dS} \cdot \mathrm{m}^{-1}$ were collected. The soil analyses were done at the soil laboratory of the Gilat Experimental Station. EC and chloride concentration were done in saturated soil extracts (Sparks, 1996).

Statistical analysis. At least three replicates were used for each field test. The data were statistically analyzed with JMP software using the Tukey-Kramer honestly significant difference test or Fisher's test for determining significant differences among the treatments at $P \leq 0.01,0.05$, or 0.001 .

\section{Results and Discussion}

The vegetative and reproductive response of mature yielding trees of many olive cultivars commonly cultivated in Mediterranean countries to irrigation with saline water has not yet been studied in intensive orchard conditions. Previous studies carried out with mature yielding trees of common local Israeli 'Barnea' cultivar trees cultivated in an orchard irrigated with three levels of saline water $\left(1.2,4.2\right.$, and $\left.7.5 \mathrm{dS} \cdot \mathrm{m}^{-1}\right)$ clearly showed the advantage of using $4.2 \mathrm{dS} \cdot \mathrm{m}^{-1}$ water for optimization of the horticultural performance of 'Barnea' trees in terms of growth and olive yield (Klein et al., 1994; Wiesman et al., 2002, 2004). As a follow up to these studies, the response of 12 selected olive cultivars from Mediterranean olivegrowing countries to saline irrigation water was analyzed in a special saline-irrigated experimental plot established at the Ramat Negev Station in 1997 (Table 1). This plot was irrigated with moderate saline water (4.2 $\left.\mathrm{dS} \cdot \mathrm{m}^{-1}\right)$ and tap water $\left(1.2 \mathrm{dS} \cdot \mathrm{m}^{-1}\right)$ and was used as a simulation of a commercial olive plantation in a semiarid area. The data collected during 5 years of intensive drip irrigation cultivation under orchard conditions are presented in this study and the results are discussed.

Trunk development. It is well established that the response of olive trees to salinity changes during different developmental stages of the tree (Aragues et al., 2005; Gucci and Tattini, 1997; Wiesman et al., 2004). To evaluate the vegetative response of mature olive trees to saline irrigation water, the changes in trunk circumference were recorded in the present study. Changes, over 5 years, in the trunk circumference of mature olive cultivars irrigated with moderate saline water $\left(4.2 \mathrm{dS} \cdot \mathrm{m}^{-1}\right)$ in comparison with tap water $\left(1.2 \mathrm{dS} \cdot \mathrm{m}^{-1}\right)$-irrigated trees of the same cultivars are presented in Table 3 . In agreement with many of the reports available concerning olive tree development in saline conditions (Aragues et al., 2005; Bouaziz, 1990; Chartzoulakis, 2005; Cresti et al., 1994; Klein et al., 1992, 1994; Wiesman et al., 2004), a pattern of increased trunk circumference was observed in control trees compared with saline-irrigated trees in the first three years (2001 to 2003). However, no significant differences were found between the two treatments. In the next 2 years (2004 to 2005), this pattern changed and the salineirrigated trunk circumference seemed to 
Table 5. Comparison of olive oil percent in all tested olive cultivars irrigated with saline water versus irrigation with tap water.

A. Olive oil percent analysis in the time period 2001 to 2004 .

\begin{tabular}{|c|c|c|c|c|c|c|}
\hline \multirow[b]{2}{*}{ Cultivar } & \multirow{2}{*}{$\begin{array}{l}\text { Salinity } \\
\left(\mathrm{dS} \cdot \mathrm{m}^{-1}\right)\end{array}$} & \multicolumn{4}{|c|}{ Oil content $(\%)$} & \multirow[b]{2}{*}{ Avg } \\
\hline & & 2001 & 2002 & 2003 & 2004 & \\
\hline \multicolumn{7}{|l|}{ Israeli origin } \\
\hline Barnea & 1.2 & $21.8 \mathrm{~b}$ & $22.9 \mathrm{a}$ & $21.7 \mathrm{a}$ & $16.0 \mathrm{~b}$ & $20.4 \mathrm{a} \mathrm{x}$ \\
\hline Barnea & 4.2 & $25.7 \mathrm{a}$ & $21.1 \mathrm{a}$ & $18.7 \mathrm{~b}$ & $19.3 \mathrm{a}$ & 19.6 a x y \\
\hline Souri & 1.2 & $20.3 \mathrm{~b}$ & $16.8 \mathrm{a}$ & $23.0 \mathrm{a}$ & $21.0 \mathrm{a}$ & 20.3 a x y \\
\hline Souri & 4.2 & $25.6 \mathrm{a}$ & $18.7 \mathrm{a}$ & $16.4 \mathrm{~b}$ & $21.1 \mathrm{a}$ & 19.4 a x y \\
\hline Maalot & 1.2 & $\mathrm{ND}$ & $16.5 \mathrm{a}$ & $29.8 \mathrm{a}$ & $27.4 \mathrm{a}$ & $24.6 \mathrm{a} \mathrm{x}$ \\
\hline Maalot & 4.2 & $\mathrm{ND}$ & $17.3 \mathrm{a}$ & $19.3 \mathrm{~b}$ & $29.2 \mathrm{a}$ & $22.0 \mathrm{ax}$ \\
\hline \multicolumn{7}{|l|}{ Italian origin } \\
\hline Frantoio & 1.2 & $14.0 \mathrm{~b}$ & $17.4 \mathrm{~b}$ & 0.0 & $19.5 \mathrm{~b}$ & 12.5 a y \\
\hline Frantoio & 4.2 & $19.1 \mathrm{a}$ & $23.0 \mathrm{a}$ & 0.0 & $23.5 \mathrm{a}$ & 15.9 a х y \\
\hline Leccino & 1.2 & $25.6 \mathrm{a}$ & $14.7 \mathrm{a}$ & $19.5 \mathrm{a}$ & $15.4 \mathrm{~b}$ & 17.5 a x y \\
\hline Leccino & 4.2 & $16.7 \mathrm{~b}$ & $13.1 \mathrm{a}$ & $18.6 \mathrm{a}$ & $17.6 \mathrm{a}$ & 16.6 a x y \\
\hline \multicolumn{7}{|l|}{ Spanish origin } \\
\hline Arbequina & 1.2 & $19.0 \mathrm{~b}$ & $13.1 \mathrm{a}$ & $21.1 \mathrm{a}$ & $21.7 \mathrm{~b}$ & 18.7 a x y \\
\hline Arbequina & 4.2 & $26.7 \mathrm{a}$ & $12.9 \mathrm{a}$ & $17.1 \mathrm{~b}$ & $25.5 \mathrm{a}$ & 19.3 a x y \\
\hline Picual & 1.2 & $15.7 \mathrm{a}$ & $13.2 \mathrm{a}$ & $16.9 \mathrm{a}$ & $13.7 \mathrm{a}$ & 14.7 a y \\
\hline Picual & 4.2 & $16.5 \mathrm{a}$ & $14.2 \mathrm{a}$ & $13.3 \mathrm{~b}$ & $15.0 \mathrm{a}$ & 14.7 a y \\
\hline Picudo & 1.2 & $14.4 \mathrm{a}$ & $12.5 \mathrm{a}$ & $21.9 \mathrm{a}$ & $15.8 \mathrm{a}$ & 16.5 a x y \\
\hline Picudo & 4.2 & $13.5 \mathrm{a}$ & $11.9 \mathrm{a}$ & $20.0 \mathrm{a}$ & $15.2 \mathrm{a}$ & 15.5 a x y \\
\hline \multicolumn{7}{|l|}{ Greek origin } \\
\hline Kalamata & 1.2 & ND & $8.9 \mathrm{a}$ & $22.5 \mathrm{a}$ & $18.2 \mathrm{a}$ & 16.6 a x y \\
\hline Kalamata & 4.2 & ND & $7.3 \mathrm{a}$ & $18.9 \mathrm{~b}$ & $19.7 \mathrm{a}$ & 15.4 a x y \\
\hline Koroneiki & 1.2 & $15.0 \mathrm{~b}$ & $18.4 \mathrm{~b}$ & $21.9 \mathrm{a}$ & $19.9 \mathrm{a}$ & 19.6 a x y \\
\hline Koroneiki & 4.2 & $22.1 \mathrm{a}$ & $23.1 \mathrm{a}$ & $20.4 \mathrm{~b}$ & $18.5 \mathrm{a}$ & 20.9 a x \\
\hline \multicolumn{7}{|l|}{ French origin } \\
\hline Picholin & 1.2 & $20.3 \mathrm{a}$ & $15.6 \mathrm{a}$ & ND & $16.7 \mathrm{a}$ & 16.8 a x y \\
\hline Picholin & 4.2 & $20.2 \mathrm{a}$ & $16.0 \mathrm{a}$ & $\mathrm{ND}$ & $11.0 \mathrm{~b}$ & $14.4 \mathrm{a} \mathrm{y}$ \\
\hline \multicolumn{7}{|l|}{ Morocco origin } \\
\hline P. Morocco & 1.2 & ND & $12.6 \mathrm{a}$ & $11.9 \mathrm{a}$ & $15.8 \mathrm{a}$ & 13.5 a y \\
\hline P. Morocco & 4.2 & $\mathrm{ND}$ & $14.0 \mathrm{a}$ & $11.7 \mathrm{a}$ & $16.2 \mathrm{a}$ & 13.8 a y \\
\hline
\end{tabular}

Fisher test $(P \leq 0.05)$ was done between two saline treatment levels $\left(1.2 \mathrm{dS} \cdot \mathrm{m}^{-1}\right.$ and $\left.4.2 \mathrm{dS} \cdot \mathrm{m}^{-1}\right)$ (letters $\mathrm{a}$ and $\mathrm{b}$ ), and between all the tested cultivars in both treatments (letters $\mathrm{x}$ and $\mathrm{y}$ ). Levels not connected by same letter are significantly different.

$\mathrm{ND}=$ not detected.

Table 5B. Fisher analysis of variance of the effect of cultivars and treatments on olive oil percentage.

\begin{tabular}{lccc}
\hline Source & Degrees of freedom & F value & Significance \\
\hline Cultivar & 11 & 7.51 & $*$ \\
Treatment & 1 & 0.33 & NS \\
Cultivar*treatment & 11 & 0.56 & NS \\
\hline
\end{tabular}

*Highly significant differences at $P \leq 0.01$.

NS $=$ nonsignificant.

develop at a faster rate than control trunks, but again, no significant differences could be determined. The reason for this unexpected effect might be related to root/canopy ratio and it is currently under investigation using a minirizonthron video camera system able to take root growth measurements. In the selected local Israeli olive cultivars, 'Barnea' and 'Maalot', this changed pattern could be easily seen and in Oct. 2005; the salineirrigated 'Barnea' trunk circumference was equal to that of control trees ( $57 \mathrm{~cm}$ for both). This pattern of trunk development is in good agreement with previous reports dealing with 'Barnea' trees drip-irrigated with saline water (Klein et al., 1994; Wiesman et al., 2004). A stronger tendency for trunk growth was observed for 'Maalot' saline-irrigated trees that reached $69 \mathrm{~cm}$ in comparison with $65 \mathrm{~cm}$ in the control trees in Oct. 2005. In this case, the difference between the calculated average rate of increase in the trunks of saline-irrigated trees in comparison with control trees was even higher, 8.7 versus $6.8 \mathrm{~cm} /$ year for control trees. In agreement with most of the reports (Bouaziz, 1990;
Gucci and Tattini, 1997; Klein et al., 1994), 'Souri', the third selected Israeli olive cultivar, demonstrated a pattern of reduced trunk circumference increase in response to saline irrigation water during the whole 5-year test period. Accordingly, the calculated average trunk increase per year was higher in control trees than in saline-irrigated trees, 6.9 and $5.7 \mathrm{~cm} /$ year, respectively.

Among the Italian cultivars, 'Frantoio' showed behavior similar to 'Barnea'. In the first trunk growth phase of relatively young trees, the saline-irrigated tree trunks tend to be reduced in comparison with control trees, but later the difference diminished and the average trunk increase was greater in salineirrigated trees than in control trees. Trunk circumference values in 'Leccino' trees show a minimal difference between the two irrigation treatments during the whole course of the trial. To the best of our knowledge, no previous reports of similar saline field conditions concerning these Italian cultivars are available.

'Arbequina', a cultivar from the Spanish group, showed only minor differences between the saline-treated trees and the control trees during the entire testing period. The average trunk increase per year suggests a slightly higher rate of growth of the control trunk in comparison with the saline trunk, 5.9 versus $5.3 \mathrm{~cm} /$ year, respectively. 'Picual' trees irrigated with saline water were somewhat smaller in all measured years in comparison with control trees, but the rate of trunk growth was similar for both treatments. 'Picudo' saline-irrigated trees showed a 'Maalot' pattern type of trunk growth that began with a greater trunk circumference in the control trees and ended with a larger trunk circumference in the saline-irrigated trees.

The two cultivars from Greece, 'Kalamata' and 'Koroneiki', and 'Picholin' from France, also showed somewhat smaller initial trunk values in saline-irrigated trees than in control trees. In trees of 'Picholin di Morocco', only on the initial testing date in Nov. 2001 was the trunk circumference smaller (but not significantly) with saline treatment compared with the control, and from then on, the trunk of the saline-irrigated trees developed similarly and even at a faster rate than control trees.

Statistical analysis of trunk circumference changes of all the olive cultivars tested in the experimental plot in 2001, 2003, and 2005 clearly showed a significant difference between the olive cultivars in the three analyzed states (Table 3B). A lower rate of statistical effect of the irrigation treatments was found only at the first date (2001) and no effect of the interaction between the cultivars and irrigation treatments could be observed in this analysis at all the three tested dates. Furthermore, in Oct. 2005, 'Maalot' and 'Leccino' trees irrigated both with saline and tap water showed the most intensive trunk circumference growth, significantly greater in comparison with 'Arbequina', 'Picudo', 'Kalamata', and 'Koroneiki' trees irrigated with saline water (Table 3A). All the other olive cultivars' trunk growth was between these two groups.

The fact that no strong effect was found in terms of trunk development of all 12 olive cultivars irrigated with saline or tap water in the present study is surprising and interesting. It could be added that in terms of foliage development, no visual differences between trees irrigated with the two types of water could be observed in the two subplots from 2004 and later (data not shown). Generally, it seems that the response of most cultivars of olive trees can be divided into two phases. In the first phase of relatively young mature trees in the present study, during the fourth, fifth, and sixth years of the trees, some reduction in vegetative growth of salineirrigated trees could be observed in terms of trunk growth and, visually, in foliage height. This pattern of reduced growth in response to saline irrigation water is in good agreement with previous studies carried out under the same conditions (Klein et al., 1994; Wiesman et al., 2004) and also with most other reports dealing with the growth-reducing effect of saline on young olive trees (Aragues et al., 
Table 6. Comparison of olive oil yield in all tested olives cultivars irrigated with saline water versus irrigation with tap water.

A. Olive oil yield analysis in the time period 2001 to 2004.

\begin{tabular}{|c|c|c|c|c|c|c|}
\hline \multirow[b]{2}{*}{ Cultivar } & \multirow{2}{*}{$\begin{array}{c}\text { Salinity } \\
\left(\mathrm{dS} \cdot \mathrm{m}^{-1}\right)\end{array}$} & \multicolumn{4}{|c|}{ Oil yield $(\mathrm{kg} /$ tree $)$} & \multirow[b]{2}{*}{ Avg. } \\
\hline & & 2001 & 2002 & 2003 & 2004 & \\
\hline \multicolumn{7}{|l|}{ Israeli origin } \\
\hline Barnea & 1.2 & 8.3 & 12.6 & 9.0 & 12.2 & $11.0 \mathrm{a} \mathrm{x}$ \\
\hline Barnea & 4.2 & 8.6 & 11.1 & 4.3 & 16.3 & $10.5 \mathrm{a} \mathrm{x}$ \\
\hline Souri & 1.2 & 1.0 & 3.4 & 7.6 & 10.7 & 6.6 a x y \\
\hline Souri & 4.2 & 1.1 & 4.2 & 6.0 & 8.5 & 5.9 a y \\
\hline Maalot & 1.2 & $\mathrm{ND}$ & 5.3 & 11.8 & 11.1 & 9.4 a x y \\
\hline Maalot & 4.2 & $\mathrm{ND}$ & 3.6 & 5.2 & 15.4 & 8.1 a $x y$ \\
\hline \multicolumn{7}{|l|}{ Italian origin } \\
\hline Frantoio & 1.2 & 1.5 & 9.5 & 0.0 & 13.0 & $7.1 \mathrm{a} \times \mathrm{y}$ \\
\hline Frantoio & 4.2 & 4.5 & 8.4 & 0.0 & 15.5 & 7.3 a $x y$ \\
\hline Leccino & 1.2 & 2.3 & 5.3 & 7.5 & 11.0 & 7.6 a $x y$ \\
\hline Leccino & 4.2 & 2.0 & 4.9 & 5.1 & 13.8 & 7.6 a x y \\
\hline \multicolumn{7}{|l|}{ Spanish origin } \\
\hline Arbequina & 1.2 & 2.3 & 5.0 & 9.2 & 11.2 & $8.1 \mathrm{ax} \mathrm{y}$ \\
\hline Arbequina & 4.2 & 6.8 & 4.1 & 8.5 & 14.8 & 9.0 a $x \mathrm{y}$ \\
\hline Picual & 1.2 & 4.8 & 5.5 & 1.8 & 10.6 & 7.8 a $x y$ \\
\hline Picual & 4.2 & 2.7 & 6.3 & 1.7 & 11.7 & 6.0 a y \\
\hline Picudo & 1.2 & 0.3 & 5.3 & 1.8 & 8.0 & 4.8 a y \\
\hline Picudo & 4.2 & 0.7 & 3.0 & 3.4 & 8.4 & 4.6 a y \\
\hline \multicolumn{7}{|l|}{ Greek origin } \\
\hline Kalamata & 1.2 & ND & 1.4 & 8.4 & 7.3 & 5.7 a x y \\
\hline Kalamata & 4.2 & $\mathrm{ND}$ & 1.1 & 7.8 & 10.2 & 6.5 a $x y$ \\
\hline Koroneiki & 1.2 & 1.6 & 9.8 & 5.3 & 11.5 & 8.4 a x y \\
\hline Koroneiki & 4.2 & 3.5 & 6.6 & 4.4 & 10.3 & 6.9 a $x y$ \\
\hline \multicolumn{7}{|l|}{ French origin } \\
\hline Picholin & 1.2 & 3.9 & 10.5 & ND & 14.8 & $11.9 \mathrm{a} \mathrm{x}$ \\
\hline Picholin & 4.2 & 5.4 & 9.1 & ND & 11.3 & 9.8 a x y \\
\hline \multicolumn{7}{|l|}{ Morocco origin } \\
\hline P. Morocco & 1.2 & $\mathrm{ND}$ & 4.3 & 2.6 & 8.5 & 5.1 a y \\
\hline P. Morocco & 4.2 & $\mathrm{ND}$ & 1.0 & 3.3 & 11.3 & $5.2 \mathrm{ay}$ \\
\hline
\end{tabular}

Fisher test $(P \leq 0.05)$ was done between two saline treatment levels $\left(1.2 \mathrm{dS} \cdot \mathrm{m}^{-1}\right.$ and $\left.4.2 \mathrm{dS} \cdot \mathrm{m}^{-1}\right)$ (letters $\mathrm{a}$ and $\mathrm{b}$ ) and between all the tested cultivars in both treatments (letters $\mathrm{x}$ and $\mathrm{y}$ ). Levels not connected by same letter are significantly different.

$\mathrm{ND}=$ not detected .

Table 6B. Fisher analysis of variance of the effect of cultivars and treatments on olive oil yield.

\begin{tabular}{lccc}
\hline Source & Degrees of freedom & F value & Significance \\
\hline Cultivar & 11 & 6.30 & $*$ \\
Treatment & 1 & 0.79 & NS \\
Cultivar*treatment & 11 & 0.38 & NS \\
\hline
\end{tabular}

*Highly significant effect at $P \leq 0.05$.

NS = nonsignificant.

2005; Bernstein, 1964; Gucci and Tattini, 1997). In the second phase, this pattern of reduction gradually changed, and the rate of growth of saline-irrigated trees increased and was even higher than in the tap waterirrigated trees. This latter response is in agreement with a previous report (Wiesman et al., 2004) done with 'Barnea' trees under the same environmental conditions and agricultural practices like in the present study. Because most of the other studies dealing with salinity and olive trees were not done for a sufficient period of time or without a comparison with tap water-irrigated trees and similar soil leaching methodologies, no comparative data are available.

In any case, the results obtained in this chapter of the study concerning the response of mature olive tree cultivars to saline irrigation water raised the question: "What is the main reason for similar vegetative response to irrigation of olive trees with saline (4.2 $\left.\mathrm{dS} \cdot \mathrm{m}^{-1}\right)$ and tap water $\left(1.2 \mathrm{dS} \cdot \mathrm{m}^{-1}\right)$ ?" Addressing this question may enable significant improvement in olive cultivation in semiarid areas using saline water for irrigation. Before trying to directly address this question, some additional horticultural parameters characterizing the response of mature olive cultivars to saline irrigation water should be presented.

Fruit yield. The effect of saline irrigation water on average fruit yield per tree obtained in four years (2001 to 2004) is presented in Table 4. General fluctuation in tree productivity is easily observed among all the olive cultivars across the various years analyzed in this study. Indeed, fluctuation of olive tree yield is a common phenomenon resulting from alternate bearing (Barranco et al., 1998). However, even after clearing the alternate bearing effect, a high level of variation is still observed, and the ratio between yields of the same olive cultivar irrigated with the two types of water changes during the 4 years tested. In the following cases, control trees of 'Barnea' (2003), 'Frantoio' (2002), 'Picudo' (2002), 'Koroneiki' (2002), 'Picholin' (2002), and 'Picholin di Morocco' (2002) yielded significantly more olives than the saline- irrigated trees. Usually, but not significantly, in the next year, the yields from the salineirrigated trees tended to be greater than those of the control trees. 'Picholin' trees irrigated with saline water did not follow this order and were found to produce a significantly higher yield than the control trees in 2003 and 2004. Calculation of the average yield during the 4 analyzed years shows that no significant differences could be found between trees of all the cultivars irrigated with the two water treatments (Table 4A). The Fisher analysis of variance clearly showed on one hand a clear significant effect of olive cultivar on the rate of olive yield and on the other hand no effect of the irrigation treatments and also no effect of the interaction between cultivars and irrigation treatments (Table 4B).

Based on the available literature, it is generally reported and accepted that a significant olive yield reduction occurs in olives cultivated in saline conditions in comparison with control conditions (Gucci and Tattini, 1997). The olive yield data obtained in the present study seem to contradict this common suggestion. However, a similar pattern of variation in olive yield as found in the present study was previously reported by Bouaziz (1990) concerning saline brackish water used for irrigation of olive trees cultivated in field conditions. Murillo et al. (2000) reported that in olive trees irrigated with wastewater characterized by a salinity level between 4.3 and $6.0 \mathrm{dS} \cdot \mathrm{m}^{-1}$, an estimated $30 \%$ reduction in fruit yield is expected. Previous studies carried out in the same location and based on similar intensive agricultural practices (Klein et al., 1994, Wiesman et al., 2004) clearly showed that olive yield reduction in response to irrigation with saline water is dependent on the level of salinity in terms of EC and on proper methodology of soil leaching as discussed subsequently. Based on these studies, water containing $4.2 \mathrm{dS} \cdot \mathrm{m}^{-1}$ was chosen for commercial olive cultivation and, indeed, successful large-scale olive plantations irrigated with this type of water $\left(4.2 \mathrm{dS} \cdot \mathrm{m}^{-1}\right)$ already exist and are increasing significantly in the Ramat Negev semiarid areas (Wiesman et al., 2002).

Oil percentage and oil yield and quality. Comparison of oil percentage determination in saline- and tap water-treated trees is presented in Table 5 . The average oil percentage in the 4 tested years (2001 to 2004) showed that in all olive cultivars, no significant differences were seen between olives produced on trees irrigated with the two types of water. However, in 2001, significantly higher oil levels were obtained in salineirrigated olives compared with the control olives of 'Barnea', 'Souri', 'Frantoio', 'Arbequina', and 'Koroneiki'. The percentage of oil in the rest of the cultivars was similar in the two treatments. In 2002, other than the higher oil percent in 'Frantoio' and 'Koroneiki' saline-irrigated trees in comparison with control olives, the oil percentage was similar in most of the cultivars. In 2003, the oil percentage measured in most of the 
trees irrigated with saline water was significantly lower than in control trees. In 2004, the oil percentage of saline-irrigated 'Barnea', 'Frantoio', 'Leccino', and 'Arbequina' trees was significantly higher than in control trees. Fisher analysis of variance clearly showed a significant effect of olive cultivars on olive oil percentage, but no effect of irrigation treatments was observed and no interaction between olive cultivars and irrigation treatments could be determined (Table 5B). These data suggest that no clear common pattern of oil accumulation could be observed in response to irrigation with saline water. These results are in good agreement with previous reports concerning the effect of salinity on olive oil accumulation (Gucci and Tattini, 1997; Klein et al., 1994; Murillo et al., 2000; Wiesman et al., 2002, 2004).

Olive oil yield, one of the most important parameters from a horticultural point of view in the olive oil industry, is determined by multiplying fresh olive weight by the oil percentage; these data are presented in Table 6A. As expected, as a result of a large fluctuation in olive production and oil accumulation of all the cultivars, a large variation could be seen during the 4 tested years (2001 to 2004). A significant effect of the olive cultivars on olive oil yield was obtained (Table 6B). However, the average olive oil yield of all tested cultivars was not significantly different between the trees irrigated with saline and tap water. These data confirm previous reports concerning the effect of salinity on olive oil yield in various cultivars (Murillo et al., 2000; Wiesman et al., 2002, 2004).

A summary of average olive oil yield by the olive cultivars in response to the Negev semiarid environmental conditions and the two types of water used for irrigation suggest three main groups: Group A-'Barnea', 'Maalot', and 'Picholin'- their average oil yield ranged from 8 to $10 \mathrm{~kg} /$ tree; Group B-'Souri', 'Frantoio', 'Leccino', 'Arbequina', 'Picual', 'Kalamata', 'Koroneiki', and 'Picholin di Morroco' - their average oil yield ranged from 5 to $8 \mathrm{~kg} /$ tree; and Group C-'Picudo' - ranged from 3 to $4 \mathrm{~kg} /$ tree.

Fatty acid analysis of the olive oil produced from olives harvested from various selected olive cultivar trees irrigated with saline and tap water clearly showed that no significant effect of saline water could be obtained on the fatty acid profile of the olive oils. In all tested cases, similar GC chromatogram (not shown) of fatty acid profiles for each cultivar could be observed. This profile of similar levels of the main fatty acids (palmitic, stearic, oleic, and linoleic acids; Barranco et al., 1998), both in saline- and tap water-irrigated treatments, is clearly presented in Table 7A. Again, as shown for all previously tested horticultural parameters, the cultivar-specific genetic effect could be easily noticed in terms of effect on oleic acid level (Table 7B; further detailed description of the effect of saline irrigation water on olive oil quality is summarized in a separate manuscript, in preparation).
Table 7A. Comparison of fatty acid composition of olive oil obtained from origin representative olives cultivars irrigated with saline water versus irrigation with tap water.

\begin{tabular}{|c|c|c|c|c|c|c|}
\hline \multirow[b]{2}{*}{ Cultivar } & \multirow[b]{2}{*}{ Salinity $\left(\mathrm{dS} \cdot \mathrm{m}^{-1}\right)$} & \multicolumn{5}{|c|}{ Fatty acid profile (\%) } \\
\hline & & Palmitic $16: 0$ & Stearic 18:0 & Oleic 18:1 & Linoleic 18:2 & Others \\
\hline \multicolumn{7}{|l|}{ Israeli origin } \\
\hline Barnea & 1.2 & $13.18 \mathrm{a}$ & $2.66 \mathrm{a}$ & 68.00 a x y & $14.52 \mathrm{a}$ & $0.75 \mathrm{a}$ \\
\hline Barnea & 4.2 & $14.52 \mathrm{a}$ & $2.79 \mathrm{a}$ & 65.30 a x y & $16.30 \mathrm{a}$ & $0.91 \mathrm{a}$ \\
\hline \multicolumn{7}{|l|}{ Italian origin } \\
\hline Leccino & 1.2 & $16.22 \mathrm{a}$ & $3.38 \mathrm{a}$ & 65.14 a x y & $14.00 \mathrm{a}$ & $1.93 \mathrm{a}$ \\
\hline Leccino & 4.2 & $16.20 \mathrm{a}$ & $1.01 \mathrm{a}$ & 65.62 a x y & $14.06 \mathrm{a}$ & $1.33 \mathrm{a}$ \\
\hline \multicolumn{7}{|l|}{ Spanish origin } \\
\hline Picual & 1.2 & $10.01 \mathrm{a}$ & $1.84 \mathrm{a}$ & 70.17 a x & $10.45 \mathrm{a}$ & $3.64 \mathrm{a}$ \\
\hline Picual & 4.2 & $15.35 \mathrm{a}$ & $3.18 \mathrm{a}$ & $70.55 \mathrm{ax}$ & $8.92 \mathrm{a}$ & $1.27 \mathrm{a}$ \\
\hline \multicolumn{7}{|l|}{ Greek origin } \\
\hline Koroneiki & 1.2 & $15.17 \mathrm{a}$ & $2.20 \mathrm{a}$ & 67.95 a x y & $10.73 \mathrm{a}$ & $4.00 \mathrm{a}$ \\
\hline Koroneiki & 4.2 & $14.82 \mathrm{a}$ & $2.52 \mathrm{a}$ & $71.53 \mathrm{ax}$ & $10.12 \mathrm{a}$ & $1.11 \mathrm{~b}$ \\
\hline \multicolumn{7}{|l|}{ French origin } \\
\hline Picholin & 1.2 & $14.43 \mathrm{a}$ & $1.80 \mathrm{a}$ & 73.60 a x & $7.05 \mathrm{a}$ & $2.26 \mathrm{a}$ \\
\hline Picholin & 4.2 & $14.82 \mathrm{a}$ & $1.48 \mathrm{a}$ & $71.30 \mathrm{a} \mathrm{x}$ & $9.04 \mathrm{a}$ & $2.60 \mathrm{a}$ \\
\hline \multicolumn{7}{|l|}{ Morocco origin } \\
\hline P. Morocco & 1.2 & $11.94 \mathrm{a}$ & $3.70 \mathrm{a}$ & 65.90 a x y & $16.83 \mathrm{a}$ & $0.90 \mathrm{a}$ \\
\hline P. Morocco & 4.2 & $13.87 \mathrm{a}$ & $0.95 \mathrm{a}$ & $65.92 \mathrm{a} \times \mathrm{y}$ & $17.44 \mathrm{a}$ & $1.15 \mathrm{a}$ \\
\hline
\end{tabular}

Tukey-Kramer test $(P \leq 0.01)$ was done between two saline treatment levels $\left(1.2 \mathrm{dS} \cdot \mathrm{m}^{-1}\right.$ and $\left.4.2 \mathrm{dS} \cdot \mathrm{m}^{-1}\right)$ (letters a and $\mathrm{b}$ ) in oleic acid (18:1) and between all the tested cultivars in both treatments (letters $\mathrm{x}$ and $\mathrm{y}$ ). Levels not connected by the same letter are significantly different.

Table 7B. Tukey-Kramer analysis of variance of the effect of cultivars and treatments on olive oil oleic acid percentage.

\begin{tabular}{lccc}
\hline Source & Degrees of freedom & F value & Significance \\
\hline Cultivar & 11 & 7.75 & $*$ \\
Treatment & 1 & 0.14 & NS \\
Cultivar*treatment & 11 & 0.45 & NS \\
\hline
\end{tabular}

*Highly significant effect at $P \leq 0.01$.

NS = nonsignificant.

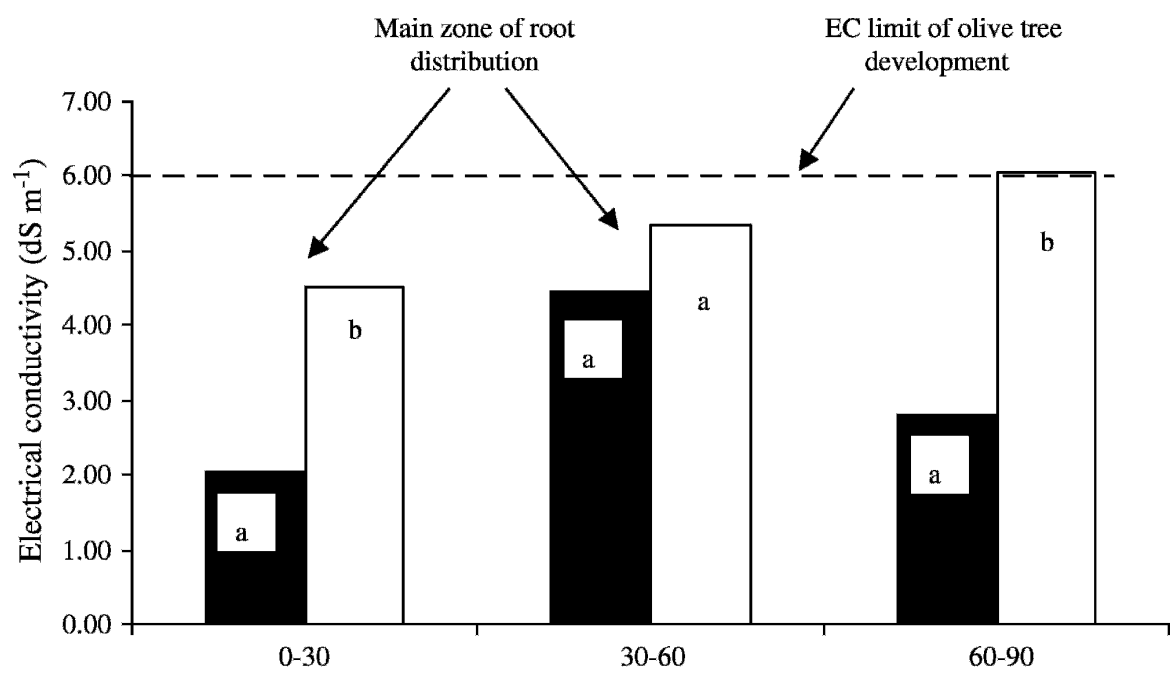

Tap Water

$\square$ Saline Water

Fig. 1. Comparison of soil fractions'electrical conductivity (EC) in the tap water subplot $\left(1.2 \mathrm{dS} \cdot \mathrm{m}^{-1}\right)$ and in the moderate saline water subplot $\left(4.2 \mathrm{dS} \cdot \mathrm{m}^{-1}\right)$. (The samples were taken in 2005 at a distance of $2 \mathrm{~m}$ from the trunk.) (A) Soil fractions analysis in 2005. Pair of bars not connected by same letter are significantly different $(P \leq 0.01)$.

(B) Tukey-Kramer analysis of variance of the effect of depth and treatment on soil fractions EC.

\begin{tabular}{lccc}
\hline Source & Degrees of freedom & F value & Significance \\
\hline Depth & 2 & 8.73 & $*$ \\
Treatment & 1 & 44.75 & $* *$ \\
Treatment*depth & 2 & 4.57 & NS \\
\hline
\end{tabular}

**Highly significant effect at $P \leq 0.01$; *low significant effect at $P \leq 0.05$.

$\mathrm{NS}=$ nonsignificant. 
Table 8 . Fisher analysis of variance of the effect of cultivars and treatments on leaf sodium and chloride ions content.

\begin{tabular}{lccccc}
\hline & \multicolumn{5}{c}{ Significance } \\
\cline { 2 - 6 } Source & Degrees of freedom & F value & $\mathrm{Na}^{+}$ & F value & $\mathrm{CL}^{-}$ \\
\hline Cultivar & 11 & 3.10 & $*$ & 1.50 & $\mathrm{NS}$ \\
Treatment & 1 & 4.52 & $\mathrm{NS}$ & 13.63 & $*$ \\
Cultivar*treatment & 11 & 0.23 & $\mathrm{NS}$ & 1.10 & $\mathrm{NS}$ \\
\hline
\end{tabular}

*Low significant effect at $P \leq 0.05$.

NS $=$ nonsignificant.

The data presented in the present study demonstrate the lack of significant response by the tested olive cultivars in the present experimental setup based on intensive drip application of saline $\left(4.2 \mathrm{dS} \cdot \mathrm{m}^{-1}\right)$ and tap water $\left(1.2 \mathrm{dS} \cdot \mathrm{m}^{-1}\right)$, suggesting that when selecting olive cultivars for cultivation in semiarid areas, most attention should be directed to the genetic differences between cultivars in terms of vegetative growth, productivity, oil yield, and quality rather than to water quality.

Soil electrical conductivity and leaf sodium and chloride analysis. To try to explain the reasons for lack of significant differences in horticultural response between the trees of various olive cultivars irrigated with saline $\left(4.2 \mathrm{dS} \cdot \mathrm{m}^{-1}\right)$ and tap water $(1.2$ $\mathrm{dS} \cdot \mathrm{m}^{-1}$ ) obtained in this study, specific soil EC in various fractions of the soil column in the root zone and leaf sodium and chloride analysis were carried out in all 12 tested olive cultivars cultivated in the experimental plot.

Study of the EC of three fractions ( 0 to 30 , 30 to 60 , and 60 to $90 \mathrm{~cm}$ ) of the soil column (Fig. 1) showed a peak of $\approx 4.5 \mathrm{dS} \cdot \mathrm{m}^{-1}$ in the middle soil fraction $(30$ to $60 \mathrm{~cm}$ ) of the tap water-irrigated trees. The pattern of soil fractions' EC level in the saline water-irrigated trees was different and showed a linear curve along the soil depth. However, the middle soil fraction that contained the main root mass and activity in this experimental plot showed no significant difference between the two irrigation treatments; the EC level of the saline irrigated soil was $5.3 \mathrm{dS} \cdot \mathrm{m}^{-1}$. In the other two soil fractions ( 0 to 30 and 60 to $90 \mathrm{~cm}$ ), a significant difference between the two irrigation treatments was obtained, but even in the lower soil fraction, the level of the EC was no more than $6 \mathrm{dS} \cdot \mathrm{m}^{-1}$. Tukey-Kramer analysis of variance clearly showed a significant effect of the irrigation treatments and a lower rate of soil depth effect (Fig. 1B). The data obtained from the EC soil fractions study are in good agreement with previous reports suggesting that most olive cultivars may develop well with no significant reduction of growth, development, and yield in a range between 3 to $6 \mathrm{dS} \cdot \mathrm{m}^{-1}$ (Aragues et al., 2005; Bernstein, 1964; FAO, 1985; Maas and Hoffman, 1977).

As a follow up, a study of leaf accumulation of sodium and chloride ions in all the olive cultivars growing in the two subplots was carried out. As could be expected and with good agreement with previously reported information (Al-Saket and Aesheh, 1987; Aragues et al., 2005; Benlloch et al., 1991; Bernstein, 1964, 1975; Gucci and
Tattini, 1997; Klein et al., 1994), the levels of sodium and chloride ions were found to be higher in leaves of saline-irrigated trees compared with tap water-irrigated trees. The highest level of sodium was found in saline irrigated leaves of 'Picual', 'Arbequina', 'Koroneiki', and 'Picholin' trees (1.455, $1.291,1.268$, and $1.125 \mathrm{mg} \cdot \mathrm{g}^{-1}$, respectively). The highest level of chloride was found in leaves of 'Picual', 'Picholin di Morroco', 'Kalamata', and 'Souri' (1.480, 1.466, 1.333 , and $1.275 \mathrm{mg} \cdot \mathrm{g}^{-1}$, respectively). In agreement with Aragues et al. (2005) who reported on growth reduction in 'Arbequina' olive trees only when leaf chloride and sodium ions levels were greater than 2.3 study, leaf content of both elements higher than these levels were not recorded in the two irrigation treatments. Interestingly, although Fisher analysis of variance showed a relatively low significant effect on the olive cultivars of sodium accumulation in the leaves, no significant effect of the cultivars was obtained for chloride (Table 8). The irrigation treatments showed a relatively low significant effect only for chloride leaf accumulation, not for sodium.

Based on the data obtained in the present study, it seems that the key factor for cultivation of various olive cultivars using moderate saline water for irrigation lies in the ability to maintain the EC of the soil in the root zone growth area at a level lower than $6 \mathrm{dS} \cdot \mathrm{m}^{-1}$, as suggested in the FAO (1985) recommendation for olive cultivation and supported by many other reports (Aragues et al., 2005; Bernstein, 1964; Maas and Hoffman, 1977). In semiarid regions, where most of the crop water requirement is supplied through irrigation and water often contains large quantities of dissolved salts, salinity control is frequently a major objective of irrigation management (Shalhevet, 1994). Leaching is the process of applying more water to the crop than can be held by the root zone so that the excess water drains below the root system, carrying salts with it (Grattan and Oster, 2002; Shalhevet, 1994). When saline water is supplied to crops, leaching becomes indispensable to exclude or reduce the excess salt from the root influence zone (Beltran, 1999). Therefore, a proper leaching methodology during the entire year was developed specifically for olive cultivation in semiarid areas and had been used in previous studies carried out in the Ramat Negev area (Wiesman et al., 2002, 2004). In the previous study with 'Barnea' olives irrigated with three levels of saline and $1.5 \mathrm{mg} \cdot \mathrm{g}^{-1}$, respectively, in the present irrigation water $\left(1.2,4.2\right.$, and $\left.7.5 \mathrm{dS} \cdot \mathrm{m}^{-1}\right)$, the soil leaching enabled cultivation of trees irrigated with the three levels of saline. However, a gradual and significant reduction of vegetative and reproductive development of the $7.5 \mathrm{dS} \cdot \mathrm{m}^{-1}$, in comparison with the other lower saline treatments, suggested that in the long-term, $7.5 \mathrm{dS} \cdot \mathrm{m}^{-1}$ water is not suitable for sustainable olive cultivation as had been suggested in many previous reports (Aragues et al., 2005; Bernstein, 1964; FAO, 1985; Maas and Hoffman, 1977). In the present study, the leaching methodology based on drip irrigation was further developed. It was found that application of an additional $1000 \mathrm{~m}^{3} \cdot$ ha of saline water $(4.2$ $\mathrm{dS} \cdot \mathrm{m}^{-1}$ ) in March at the end of the winter season and in November at the beginning of the next winter (Table 2) enabled reduction of the salt level in the developing root zone to a level lower than $6 \mathrm{dS} \cdot \mathrm{m}^{-1}$, which is essential for normal olive development. This leaching process, together with accurate weekly drip irrigation, kept the soil conditions well set for most of the tested olive cultivars to develop very similarly to the tap water-irrigated trees of the same cultivar. Interestingly, using a minirhizotron system based on a video camera, it was found that the roots of both salineand tap water-irrigated olive trees seem to be highly distributed in the two upper soil fractions (data not shown, manuscript in preparation). The EC in these soil fractions is lower than the upper level of $6 \mathrm{dS} \cdot \mathrm{m}^{-1}$, which is well-recognized as limiting olive cultivars regular development (FAO, 1985).

The data obtained in the present study clearly show the ability to cultivate all the tested olive cultivars in a semiarid area with moderate saline water irrigation. A significant variation in terms of horticultural performance was found between the various tested olive cultivars. These differences may be attributed to the natural characteristics of each cultivar or to their rate of adaptation to the environmental conditions in the tested area rather than related to the moderate saline drip irrigation in this study.

\section{Literature Cited}

Al-Saket, I.A. and I.A. Aesheh. 1987. Effect of saline water on the growth of young olive trees. Dirasat 14:7-17.

Aragues, R., J. Puy, A. Royo, and J.L. Espada. 2005. Three-year field response of young olive trees (Olea europea L., cv. Arbequina) to soil salinity: Trunk growth and leaf ion accumulation. Plant Soil 271:265-273.

Barranco, D., R. Fernandez, and L. Rallo. 1998. Variedades y partones del cultivo del olivo, $\mathrm{p}$. 61-87. In: D. Barranco, R. Fernandez-Escobar, and L. Rallo (eds.). El Cultivo Del Olivo. Junta de Andalucia, Seville, Spain.

Beltran, J.M. 1999. Irrigation with saline water: Benefits and environmental impact. Agric. Water Manage. 40:183-194.

Benlloch, M., F. Arboleda, D. Barranco, and R. Fernandez-Escobar. 1991. Response of young olive trees to sodium and boron excess in irrigation water. HortScience 26:867-870.

Bernstein, L. 1964. Effects of salinity on mineral composition and growth of plants. In: Proc. 
Fourth Int. Coll. Plant Analysis and Fertilizer Problems 4:25-45.

Bernstein, L. 1975. Effect of salinity and sodicity on plant growth. Ann. Rev. Phytopathol. 13:295-312.

Bongi, G. and F. Loreto. 1989. Gas-exchange properties of salt-stressed olive (Olea europea L.) leaves. Plant Physiol. 90:1408-1416.

Bouaziz, A. 1990. Behaviors of some olive varieties irrigated with brackish water and growth intensively in the central part of Tunisia. Acta Hort. 286:247-250.

Chartzoulakis, K.S. and H. Ragab. 2005. Salinity and olive: Growth, salt tolerance, photosynthesis and yield. Agr. Water Mgmt. 78:108-121.

Cresti, M., F. Ciampolini, M. Tattini, and A. Cimato. 1994. Effect of salinity on productivity and oil quality of olive (Olea europea L.) plants. Adv. Horticult. Sci. 8:211-214.

FAO (Food and Agriculture Organization). 1985. Water quality for agriculture. FAO Irrigation and Drainage Paper 29, Rome, Italy.

FAO (Food and Agriculture Organization). 1989. Statistical databases. Oct. 2006. <www.fao.org>.

Grattan, S.R. and J.D. Oster. 2002. Use and reuse of saline-sodic waters for irrigation of crops. In: S.S. Goyal, S.K. Sharma, and D.W. Rains (eds.). Crop production in saline environments. Journal of Crop Production. Vol. 2. Haworth Press, New York.

Gucci, R. and M. Tattini. 1997. Salinity tolerance in olive. Hort. Rev. (Amer. Soc. Hort. Sci.) 21:177-214.

Hassan, M.M., S.A. Seif, and M.E. Morsi. 2000. Salt tolerance of olive trees. Egyptian J. Hort. 27:105-116.

IOOC. 1995. Trade standard applying to olive oil and olive-pomace oil. CO/T.15.Nc no. 2/Rev. 2, 1 June.

IUPAC. 1992. Standard method for the analysis of oils, fats and derivatives. 7th ed. Pergamon Press, Oxford, UK.

Klein, I., Y. Ben Tal, S. Lavee, and I. David. 1992. Olive irrigation of saline water [in Hebrew]. Volcani Center Report, Bet-Dagan, Israel.

Klein, I., Y. Ben Tal, S. Lavee, Y. De Malach, and I. David. 1994. Saline irrigation of cv. Manzanillo and Uovo De Piccione trees. Acta Hort. 356:176-180.

Maas, E.V. and S.R. Grattan. 1999. Crop yields as affected by salinity. In: R.W. Skaggs and J. van Schilfgaarde (eds.). Agricultural drainage. Agron Monogr 38. ASA, CSSA, SSA, Madison, WI. p. $55-108$.
Maas, E.V. and G.J. Hoffman. 1977. Crop salt tolerance - Current assessment. J. Irrig. Drainage Div. ASCE 103:115-134.

Munns, R. 1993. Physiological processes limiting plant growth in saline soil: Some dogmas and hypotheses. Plant Cell Environ. 16:15-24.

Murillo, J.M., R. Lopez, J.E. Fernandez, and F. Cabrera. 2000. Olive tree response to irrigation with wastewater from the table olive industry. Irrig. Sci. 19:175-180.

Shalhevet, J. 1994. Using water of marginal water quality for crop production. Agr. Water Mgmt. 25:233-269.

Sparks, D.L. (ed.). 1996. Methods of soil analysis: Part 3, Chemical methods and processes Soil Sci. Soc. Am. Book Series 5, SSSA, Madison, WI.

Tattini, M. 1994. Ionic relations of aeroponically grown olive plants during salt stress. Plant Soil 161:251-256.

Wiesman, Z., Y. David, and N. Ben Dom. 2004. Optimization of saline water level for sustainable Barnea olive and oil production in desert conditions. Sci. Hort. 100:257-266.

Wiesman, Z., Y. De Malach, and I. David. 2002. Olive and saline water-Story of success. Intl. Water \& Irrigation 22:18-21. 